\title{
SHORT COMMUNICATION \\ ATTENUATION OF MCF-7 BREAST CANCER CELL GROWTH: A COMPARISON BETWEEN THE INFLORESCENCE AND RHIZOME EXTRACT OF Etlingera corneri
}

\author{
MAZIAH GHAZALY ${ }^{1}$, GAIK EE LEE*1,2, NURUL ATHIFAH ${ }^{1}$, MUHAMAD RAZALI SALAM ${ }^{1}$, \\ KAH HOO LAU ${ }^{3}$, ABDUL LATIFF ${ }^{4}$, SYED AHMAD TAJUDDIN ${ }^{5}$ AND RAZIFAH MOHD \\ RAZALI $^{1}$
}

${ }^{1}$ Faculty of Science and Marine Environment, ${ }^{2}$ Institute of Tropical Biodiversity and Sustainable Development (IBTPL), Universiti Malaysia Terengganu, 21030 Kuala Nerus, Terengganu, Malaysia. ${ }^{3}$ Forest Research Institute Malaysia (FRIM), 52109 Kepong, Selangor, Malaysia. ${ }^{4}$ School of Environmental and Natural Resource Sciences, Faculty of Science and Technology, Universiti Kebangsaan Malaysia, 43600 Bangi, Selangor, Malaysia. ${ }^{5}$ Faculty of Bioresources and Food Industry, University Sultan Zainal Abidin, 22200 Besut, Terengganu, Malaysia.

*Corresponding author: gaik.ee@umt.edu.my

http://doi.org/10.46754/jssm.2020.07.020

Submitted final draft: 16 November 2019 Accepted: 29 November 2019

\begin{abstract}
The genus Etlingera is a tropical perennial plant of the ginger family, Zingiberaceae, and is commonly used as a natural healing remedy due to its medicinal properties including anti-inflammatory, antibacterial, antifungal and anticancer properties. This study has focused on the use of Etlingera corneri crude extract as a treatment to examine the effects on MCF- 7 breast cancer cell growth and proliferation. The plant extracts from both the inflorescence and rhizome $(0-2000 \mu \mathrm{g} / \mathrm{mL})$ were screened for cytotoxicity and reactive oxygen species (ROS) profiles in these cells. Following treatments, responses were monitored for 24 hours by MTT and dihydroethidium (DHE) 96-well plate assays. Etlingera corneri concentrations of between 15.6 and $2000 \mu \mathrm{g} / \mathrm{mL}$ significantly reduced the viability of MCF-7 breast cancer cell growth and proliferation. However, there were no significant effects on cell viability when treated with the rhizome extract of E. corneri. In spite of the different responses for cell viability, dose dependent increases of ROS production were apparent for both extracts. This may suggest that cell death responses are not directly signalled by ROS production with the inflorescence extract from E. corneri, warranting further studies of the mechanisms involved.
\end{abstract}

Keywords: Breast cancer cells (MCF-7), cellular signalling pathway, cell viability, Etlingera corneri, reactive oxygen species, Zingiberaceae.

\section{Introduction}

Breast cancer is a common morbidity in women but also to a certain extent in men. Immortal, fast growing and multi-drug resistant which characterises cancer cells present challenges for the development of effective treatments. Previously, researchers have shown the use of plant extracts for the development of chemotherapeutic drugs in cancer treatment. The Zingiberaceae is a major family of tropical rainforest plant consisting of more than 320 species in Malaysia alone (Ibrahim et al., 2014). This plant species is well known as a culinary agent and medicinal remedy and indeed has been so for centuries. Many research have been conducted on the phytochemical and the biological activities of the Zingiberaceae species e.g., the genus Etlingera, $E$. brevilabrum, E. coccinea, E. elatior, E. fenzlii, E. linguiformis, E. megalocheilos, E. pavieana and E. pyramidosphaera (Wijekoon et al.,2011; Vairappan et al., 2012; Hossan et al., 2013; Nagappan et al., 2017; Srisook et al., 2017; Sudhakaran et al., 2018). However, to date no such studies have been reported with the use of E. corneri. Therefore, the current study aimed to investigate the effects of E. corneri on MCF7 breast cancer cell viability and any responses in cellular reactive oxygen species (ROS) production which may be associated with this. 
A steady state of ROS production is important for normal cellular function and homeostasis. However, excessive ROS production can result in perturbation of function linked to altered cell signalling processes and in extreme circumstances intracellular oxidative damage to key intracellular bio-molecules (Halliwell, 2011). It is well established that overproduction of ROS in normal cells can signal apoptotic cell death (Covarrubias et al., 2008). Thus, ROS are important in key regulator of cell fate including death, growth and proliferation (Goldstein et al., 2005). In cancer cells, it is known that although abnormally high levels of ROS are common, these cells do not die but proliferate. Literature suggests that ROS may disable key tumour suppressor proteins including p53, p16 and p21 thus allowing cancer progression (Li et al., 2011).

\section{Materials and Methods}

Plant material: The inflorescence and rhizome of E. corneri were collected at Hulu Terengganu Forest Reserve. Sampling was carried out three times at the Forest Reserve between JulyNovember 2017 and a total of seven inflorescence and $1.5 \mathrm{~kg}$ (10 - 15 pieces) of rhizome were collected. A voucher specimen (Nurul Atifah \& Maziah Ghazaly 1801) was deposited in the Herbarium of Universiti Malaysia Terengganu (UMTP). The species was kept on ice prior to being processed as plant extracts. Identification of the species was made from the description by Mood and Ibrahim (2000). Etlingera corneri can be identified from other Etlingera species through its glossy red inflorescence on long peduncles with two rows of sterile bracts that are rolled outward and down at the edges. The infructescence is white when immature and turns to red at maturity.

Plant extracts: Plant samples were air dried and then extracted in $100 \%$ methanol at room temperature for one week. The extracts were then stored at $4^{\circ} \mathrm{C}$ until required for use.

Cell culture: MCF-7 breast cancer cells were maintained in Dulbecco's Modified Eagle Medium (DMEM) and supplemented with $10 \%$ fetal bovine serum, L-glutamine (2 $\mathrm{mmol} / \mathrm{L})$, penicillin $(100 \mathrm{U} / \mathrm{mL})$, streptomycin $(100 \mu \mathrm{g} / \mathrm{mL})$. The cells were cultured at $37^{\circ} \mathrm{C}$ in humidified incubator and supplemented with $5 \% \mathrm{CO}_{2}$. All adherent cells (80-95\% confluent) were treated with $E$. corneri extracts $(0-2000$ $\mu \mathrm{g} / \mathrm{mL}$ ) for 24 hours for all experiments. The extracts were removed by washing three times with PBS. Cells were detached by using trypsin prior to further experimentation.

Detection of cell viability (MTT assay): MCF-7 breast cancer cells were seeded into a 96well cell culture plate at $5.0 \times 10^{3}$ cells per well and then treated with nine concentrations $(7.8,15.6$, $31.3,62.5,125,250,500,1000$ and $2000 \mu \mathrm{g} / \mathrm{mL}$ ) of $E$. corneri extract (inflorescence and rhizome) for 24 hours. Cells were assessed for growth and viability using the (3-(4,5-dimethylthiazol2-yl)-2,5-diphenyltetrazolium bromide (MTT) assay (Merck) and compared to control with no treatment. Assays were performed colometrically at $570 \mathrm{~nm}$ using a Multiskan GO microplate reader (Thermo Fisher Scientific).

Measurement of ROS production: Dihydroethidium (DHE), a superoxide-sensitive fluorescence dye was used as an indicator for ROS production. MCF-7 breast cancer cells were cultured in a 96-well cell culture plate at a density of $5.0 \times 10^{3}$ cells per well and then treated with nine concentrations of E. corneri extract (inflorescence and rhizome) for a period of 24 hours. Cells were then incubated with DHE $(2 \mu \mathrm{M})$ for 15 minutes and ROS intensity was determined at excitation $485 \mathrm{~nm}$ and emission at $527 \mathrm{~nm}$ using a Thermo Scientific ${ }^{\mathrm{TM}}$ Varioskan $^{\mathrm{TM}} \quad$ (Thermo Fisher Scientific) fluorescence microplate reader.

Statistical analysis: All results were expressed as mean \pm standard deviation (SD). Statistical analysis T-test was carried out. Results were considered as statistically significant when $p$ value was less than $0.05(p<0.05)$.

\section{Results and Discussion}

Altered cancer cell programming results in abnormal cell signal mechanisms enabling 
multi-drug resistance and thus preventing cell death as seen in normal cells (Gutschner \& Diederichs, 2012). The present study utilised extracts from the inflorescence or rhizome of E. corneri at nine concentrations $(7.8,15.6$, $31.3,62.5,125,250,500,1000$ and $2000 \mu \mathrm{g} /$ $\mathrm{mL}$ ) for treatment of breast cancer MCF-7 cells, in order to establish any relationship with the use of said plant extracts with overall cellular reactive oxygen stress profile and cancer cells fate (proliferation). Study outcomes provide the first evidence for a role of these extracts as mediators for elevated ROS production in these cells. ROS levels significantly increased in a concentration -dependent manner after 24 hours of treatment (Figure 1A). More specifically, $E$. corneri inflorescence extract ROS production was significantly elevated compared to its control from 62.5 up to $2000 \mu \mathrm{g} / \mathrm{mL}$ whereas, for the rhizome extract of E. corneri, significance compared to control was only demonstrated at higher extract concentrations from 500 and $1000 \mu \mathrm{g} / \mathrm{mL}$ following treatment. In addition, MCF-7 cell proliferation/viability was inhibited by the inflorescence extract of E. corneri in a dose-dependent manner as compared to control (Figure 1B). By contrast, no such inhibitory effects were seen over the entire dose range utilised with the rhizome extract of E. corneri (Figure 1B).

For this study, it was initially hypothesised that inflorescence and rhizome extracts of $E$. corneri would inhibit viability and growth of MCF-7 breast cancer cells and this would be associated directly with cellular ROS production. However, study outcomes indicate that ROS production although elevated in cells on treatments with both types of extracts, cell
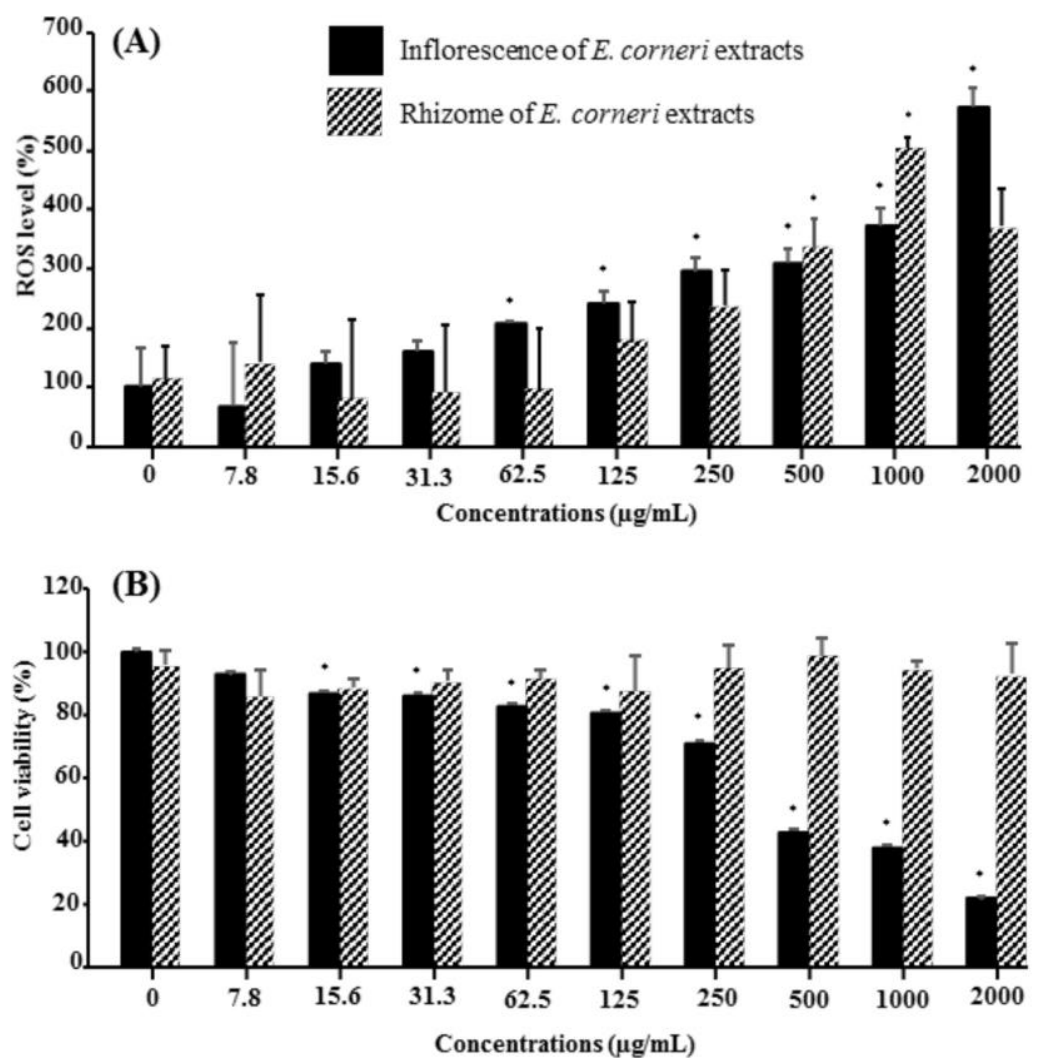

Figure 1: (A) MCF-7 cellular oxidative level and (B) MCF-7 cell viability treated with inflorescence and rhizome of E. corneri extracts 
death was only apparent with the inflorescence extract exposure. Therefore, it is not possible to conclude that there is a direct association between ROS production/signalling and that of the direct facilitator of programmed cell death on the relationship between MCF-7 following $E$. corneri treatment. This would suggest that ROS overproduction is not directly linked to cell death and that may be other yet unidentified factors/ processes are involved. Or that by suppressing other regulatory factors/controlling elements in the MCF-7 cells, a ROS mediated cell death pathway may also be enabled by the E. corneri inflorescence extract (Kumari et al., 2018). Meanwhile, others had also found that extract of the Zingiber officinale (ginger) stem had the capacity to induce apoptosis in endometrial cancer cells through the classical death signalling pathway by the activation of p53 tumour suppressor protein (Liu et al., 2012). More studies are warranted to identify this mediator and better characterise associated processes as this may lead to a better understanding of the underlying mechanisms involved following E. corneri treatment including any evidence suggesting re-programming/re-purposing of these cells for some form of cell death, apoptotic or otherwise.

\section{Acknowledgements}

A part of this work was supported by the Ministry of Education (MOE) Malaysia through Fundamental Research Grant Scheme (FRGS/1/2018/WAB13/UMT/03/1) awarded to G. E. Lee. We thank Dr. Gregory Quinlan for scrutinizing and commenting in the details of the text and the anonymous reviewers for their valuable suggestions on our manuscript.

\section{References}

Covarrubias, L., Hernández-García, D., Schnabel, D., Salas-Vidal, E. \& CastroObregón, S. (2008) Function of reactive oxygen species during animal development: passive or active? Developmental Biology, 320, 1-11.
Goldstein, B.J., Mahadev, K. \& Wu, X. (2005) Redox paradox: insulin action is facilitated by insulin-stimulated reactive oxygen species with multiple potential signaling targets. Diabetes, 54, 311-321.

Gutschner, T. \& Diederichs, S. (2012) The hallmarks of cancer: a long non-coding RNA point of view. RNA Biology, 9(6), 703-719.

Halliwell, B. (2011) Free radicals and antioxidants-quo vadis? Trends in Pharmacological Sciences, 32, 125-130.

Hossan, M.A., Ibrahim, M., Ahsan, M.Q., Aktar, F., Kuddus, M.R., Chowdhury, M.M.U. \& Rashid, M.A. (2013) Pharmacological and phytochemical screening of ethanol extract of Etlingera linguiformis (Roxb.) R.M.Sm. growing in Bangladesh. Bangladesh Pharmaceutical Journal, 16, 33-37.

Ibrahim, H., Khalid, N. \& Hussin, K. (2014) Cultivated gingers of Peninsular Malaysia: Utilization, profiles and micropropagation. Gardens'Bulletin Singapore, 59, 71-88.

Kumari, S., Badana, A.K., G, M.M., G, S. \& Malla, R. (2018) Reactive Oxygen Species: A Key Constituent in Cancer Survival. Biomarker Insights, 13, 1-9.

Li, J., Poi, M.J. \& Tsai, M.D. (2011) Regulatory mechanisms of tumor suppressor P16INK4A and their relevance to cancer. Biochemistry, 50, 5566-5582.

Liu, Y., Whelan, R.J., Pattnaik, B.R., Ludwig, K., Subudhi, E., Rowland, H. (...) \& Kapur, A. (2012) Terpenoids from Zingiber officinale (Ginger) induce apoptosis in endometrial cancer cells through the activation of p53. PloS one, 7(12), e53178. doi:10.1371/ journal.pone. 0053178 .

Mood, J. \& Ibrahim, H. (2000) A new species of Etlingera (Zingiberaceae) from Peninsular Malaysia and southern Thailand. Nordic Journal of Botany, 20, 279-283.

Nagappan, T., Yatau, M.H., Salim, J.M. \& Vairappan, C.S. (2017) Diversity in volatile chemicals and antibacterial activity among 
selected genus Cinnamomum, Etlingera and Schizostachyum from Sabah. Journal of Sustainability Science and Management, 12, 23-33.

Srisook, E., Palachot, M., Mankhong, S. \& Srisook, K. (2017) Anti-inflammatory effect of Etlingera pavieana (Pierre ex Gagnep.) R.M.Sm. rhizomal extract and its phenolic compounds in lipopolysaccharidestimulated macrophages. Pharmacognosy Magazine, 13, 230-235.

Sudhakaran, A., Kumar, R. \& Radha, R.K. (2018) Antioxidant activity of methanolic leaf extract of Etlingera fenzlii (Kurz)
Skronick. \& M.Sabu (Zingiberaceae) - The honey bee repellent endemic plant species of the Andaman Nicobar Islands. Annals of Plant Sciences, 7, 2296-2301.

Vairappan, C.S., Nagappan, T. \& Palaniveloo, K. (2012) Essential oil composition, cytotoxic and antibacterial activities of five Etlingera species form Borneo. Natural Products Communications, 7, 239-242.

Wijekoon, J.O., Karim, M.M. \& Bhat, R. (2011) Evaluation of nutritional quality of torch ginger (Etlingera elatior Jack.) inflorescence. International Food Research Journal, 18, 1415-1420. 